Old Dominion University

ODU Digital Commons

VMASC Publications

Virginia Modeling, Analysis \& Simulation Center

2012

\title{
Identifying Factors that Influence Terrorist Decisions and Target Selection
}

Barry C. Ezell

Old Dominion University, bezell@odu.edu

Joshua Behr

Old Dominion University, jbehr@odu.edu

Andrew Collins

Old Dominion University, acollins@odu.edu

Follow this and additional works at: https://digitalcommons.odu.edu/vmasc_pubs

Part of the Defense and Security Studies Commons, Emergency and Disaster Management Commons, Public Policy Commons, and the Terrorism Studies Commons

\section{Repository Citation}

Ezell, Barry C.; Behr, Joshua; and Collins, Andrew, "Identifying Factors that Influence Terrorist Decisions and Target Selection" (2012). VMASC Publications. 17.

https://digitalcommons.odu.edu/vmasc_pubs/17

\section{Original Publication Citation}

Ezell, B. C., Behr, J., \& Collins, A. (2012). Identifying factors that influence terrorist decisions and target selection. Journal of Homeland Security and Emergency Management, 9(1), 8. doi:10.1515/1547-7355.1974

This Article is brought to you for free and open access by the Virginia Modeling, Analysis \& Simulation Center at ODU Digital Commons. It has been accepted for inclusion in VMASC Publications by an authorized administrator of ODU Digital Commons. For more information, please contact digitalcommons@odu.edu. 


\section{Journal of Homeland Security and Emergency Management}

Volume 9, Issue 1 2012

Article 8

\section{Identifying Factors that Influence Terrorist Decisions and Target Selection}

Barry C. Ezell, Virginia Modeling, Analysis, and Simulation Center, Old Dominion University

Joshua Behr, Virginia Modeling, Analysis, and Simulation Center, Old Dominion University Andrew Collins, Virginia Modeling, Analysis, and Simulation Center, Old Dominion University

Recommended Citation:

Ezell, Barry C.; Behr, Joshua; and Collins, Andrew (2012) "Identifying Factors that Influence Terrorist Decisions and Target Selection," Journal of Homeland Security and Emergency Management: Vol. 9: Iss. 1, Article 8.

DOI: $10.1515 / 1547-7355.1974$

C2012 De Gruyter. All rights reserved. 


\title{
Identifying Factors that Influence Terrorist Decisions and Target Selection
}

\author{
Barry C. Ezell, Joshua Behr, and Andrew Collins
}

\begin{abstract}
Currently, the U.S. Department of Homeland Security (DHS) elicits probabilistic judgments from the intelligence community on actions terrorists may take to attack the continental U.S. For example, how likely is the adversary to choose agent ' $x$ ' over agent ' $y$ ' or target ' $a$ ' over target ' $b$ '? Eliciting these types of judgments is difficult and time consuming. The National Academies and others have suggested that a better approach may be to elicit information on adversary's preferences, perceptions, and capabilities and use this information to calculate probabilities of interest to DHS. Some terrorist groups are thinking about using weapons of mass destruction (WMD), each with its own values, perceptions of reality, and capabilities. This presentation details the findings on the factors \& relationships among factors that lead to a terrorist decision to initiate an attack against the continental U.S as well as target selection. To accomplish this, we assembled international experts in WMD, adversary modeling, political science, terrorism, psychiatry, social sciences as well as experts from national laboratories, the Commonwealth of Virginia State Fusion Center, and Hampton Roads Emergency Management.

This paper provides a summary of the findings from an Adaptive Adversary Workshop. In this paper, we provide an overview of the motivation for and design of the workshop as well as 19 emerging themes. The purpose of the workshop was to illicit expert opinions on terrorist decisionmaking and target selections in an effort to improve our understanding of adversaries (individuals, local/regional groups, transnational groups, states) who may initiate a bioterrorism attack in the form of releasing biological agents upon U.S. interests. Furthermore, these expert opinions are intended to be used to inform Bayesian Belief Network (BBN) models of terrorist networks. These models must be informed or populated with substantive information about the intelligent and adaptive adversary who may initiate an attack. To this end, a conceptual framework, informed broadly by the social sciences community, is intended to capture the terrorists' motivations, methods, and decision calculi.
\end{abstract}

KEYWORDS: Adaptive Adversary Factors, terrorism, terrorist decisions

Author Notes: This work was funded in part by the Battelle National Biodefense Institue Contract \# 792981. 
Currently, the U.S. Department of Homeland Security (DHS) elicits probabilistic judgments from the intelligence community on actions that terrorists may take to attack the continental United States (CONUS). For example, how likely is the adversary (terrorist) to choose agent $X$ over agent $Y$ or target $A$ over target $B$ ? But eliciting such judgments is difficult and time-consuming. Some terrorist groups are thinking about using weapons of mass destruction (WMD), each group having its own values, perceptions of reality, and capabilities. The National Academies and others have suggested that a better approach might be to elicit information on the adversary's values, perceptions, and capabilities and use that information to calculate probabilities of interest to DHS.

\section{Adaptive Adversary Workshop}

The Adaptive Adversary Workshop was a one-day workshop focused on determining the factors that lead to a terrorist decision to initiate an attack against CONUS as well as to the selection of targets. To this end, we assembled international experts in WMD, adversary modeling, political science, terrorism, psychiatry, and social sciences; professionals from local law enforcement, the DHS Office of Risk Management, the Commonwealth of Virginia State Fusion Center, Hampton Roads Emergency Management, and the Hampton Roads Planning District Commission; and experts from the Sandia National Laboratories. These experts included Dr. Jessica Stern of the Hoover Institution's Task Force on National Security and Law, who also served on President Bill Clinton's National Security Council staff in 1994-1995; Dr. Ian Lustick, professor of political science at the University of Pennsylvania, who has written and edited more than twenty books on terrorism-related issues; Dr. John Lathrop of Strategic Insights, whose research focuses on counterterrorism and risk management accounting for the adaptive adversary; and Mr. George Gabriel, manager for security, preparedness, and emergency management for Whitney Bradley and Brown Inc., who recently authored the terrorism response plan for the city of Newport News, Virginia.

The invited participants were given the opportunity to make presentations based on their own research and experience on the subject of terrorism. They were then asked to engage in three moderated discussion-based sessions addressing factors influencing terrorist attack decisions, target selections, and prevailing taxonomies. Other invited participants were encouraged to ask questions and provide input via a live streaming blog during the discussions. These discussions were captured and data were collected via audio recording, written transcript, and data collector notes. 


\section{Emerging Themes}

Findings covered nineteen themes ranging from individual motivations to group dynamics, U.S. response strategies, undisclosed terrorist motivations, and modeling methodologies. These themes are shown in the table below.

\begin{tabular}{|c|c|c|}
\hline & Title & Description \\
\hline 1 & $\begin{array}{l}\text { Threat Shifting: } \\
\text { Shell Game or } \\
\text { Not? }\end{array}$ & $\begin{array}{l}\text { Terrorists do in fact respond to countermeasures. An increase in } \\
\text { vigilance and security at a venue decreases the likelihood of an } \\
\text { attack at that venue. Although it is recognized that the threat may } \\
\text { shift to other targets, target hardening still has the effect of reducing } \\
\text { targets and decreasing the overall probability of an attack. }\end{array}$ \\
\hline 2 & $\begin{array}{l}\text { Two Cultures } \\
\text { (Modelers and the } \\
\text { Intel Community) }\end{array}$ & $\begin{array}{l}\text { The challenge is to understand the terrorists' objectives so that their } \\
\text { decision-making processes may be modeled. To do this, modelers } \\
\text { need to closely collaborate with experts within the intelligence } \\
\text { community to gain a better understanding of the objectives of the } \\
\text { radial Islamists, their hierarchy, etc. The important point is that we } \\
\text { don't build models first and elicit the opinions of experts afterward. } \\
\text { We need to start with the narratives of terrorist processes and then } \\
\text { fit our tools to that. Unfortunately, the connection between the } \\
\text { expert intelligence and tool fitting has not yet been made. }\end{array}$ \\
\hline 3 & $\begin{array}{l}\text { Organized Crime, } \\
\text { Organized } \\
\text { Terrorism }\end{array}$ & $\begin{array}{l}\text { Terrorism is not an individual, isolated person or attack but rather } \\
\text { an enterprise with leadership. Therefore, organized terrorism can be } \\
\text { approached in much the same manner as organized crime. With } \\
\text { such an approach it is imperative to focus on and understand the } \\
\text { hierarchal structure of the organization, not the motivations of the } \\
\text { individual. Debilitating the overall structure of the organization } \\
\text { minimizes the consequences of any attacks. }\end{array}$ \\
\hline 4 & $\begin{array}{l}\text { Homegrown } \\
\text { Violent Extremist } \\
\text { (HGVE) }\end{array}$ & $\begin{array}{l}\text { Exportation of terrorism gives us opportunities to monitor terrorist } \\
\text { travel and communications, but this is not the case with the HGVE. } \\
\text { We are now seeing the radicalized homegrown terrorist; less } \\
\text { controllable by an organization, this type of radical is, by extension, } \\
\text { less predictable in the size and nature of the act he may commit. } \\
\text { This unpredictability is exacerbated by a lack of understanding as to } \\
\text { what motivates the HGVE. }\end{array}$ \\
\hline 5 & $\begin{array}{l}\text { Cover All My } \\
\text { Bases }\end{array}$ & $\begin{array}{l}\text { Terrorists are heavily invested in instilling fear and breaking down } \\
\text { the bonds of trust between society and government, as well as in } \\
\text { disrupting the economy and forcing states and organizations to } \\
\text { continue investing heavily in counterterrorism measures. As a } \\
\text { consequence, we become locked in a fear, blame, and spending } \\
\text { spiral, underscoring huge discrepancies between our risk } \\
\text { perceptions and the probability of actual attacks. }\end{array}$ \\
\hline \multirow[t]{2}{*}{6} & \multirow{2}{*}{$\begin{array}{l}\text { Political Violence } \\
\text { as a Dramatic } \\
\text { Production } \\
\text { (Terrorism is } \\
\text { Theater) with Four }\end{array}$} & $\begin{array}{l}\text { Solipsistic terrorism: I hit you and I show us; recruiting cast } \\
\text { members. The objective is not necessarily to kill or harm as many } \\
\text { Americans as possible but, rather, to inspire recruitment. }\end{array}$ \\
\hline & & $\begin{array}{l}\text { Judo: I hit you, you hit me, but help me hit yourself even harder; } \\
\text { triggering audience to attack the stage. What the terrorist really }\end{array}$ \\
\hline
\end{tabular}




\begin{tabular}{|c|c|c|}
\hline & Title & Description \\
\hline & \multirow[t]{3}{*}{$\begin{array}{l}\text { Types of } \\
\text { Interactions }\end{array}$} & $\begin{array}{l}\text { wants here is an overreaction, exposing the target to more costs and } \\
\text { exaggerated threats. The optimal response to this tactic is to } \\
\text { minimize the effects by not overreacting. }\end{array}$ \\
\hline & & Ricochet: I hit you, you hit me. \\
\hline & & $\begin{array}{l}\text { Classic terrorism: Most advanced; it is rare. We are not there yet; } \\
\text { essentially, we are going to attack you until you stop. This is what } \\
\text { the United States did to Japan. }\end{array}$ \\
\hline 7 & $\begin{array}{l}\text { Natural Systems } \\
\text { Paradigm }\end{array}$ & $\begin{array}{l}\text { Terrorist organizations exist on a spectrum from accomplishment of } \\
\text { goals - changing the world, expressing themselves to an } \\
\text { audience- to maintenance of goals-keeping members, raising } \\
\text { funds, and taking care of their supports. When organizations shift to } \\
\text { pure maintenance objectives, they begin to strategically plan attacks } \\
\text { for the purpose of recruitment. As a consequence they often } \\
\text { transition into a purely criminal organization. The instrumental goal } \\
\text { of changing the world thus becomes a marketing strategy. }\end{array}$ \\
\hline 8 & $\begin{array}{l}\text { Terrorism as a } \\
\text { Mark of Identity }\end{array}$ & $\begin{array}{l}\text { Individuals are drawn to terrorist organizations for numerous reasons, } \\
\text { including money, power, and prestige, and often for a sense of } \\
\text { belonging-an identity with dignity. This identity with dignity is a } \\
\text { powerful motivation for joining and is often the initial reason. It is } \\
\text { not until later on that recruits become indoctrinated and adopt the } \\
\text { ideology of the organization. }\end{array}$ \\
\hline 9 & $\begin{array}{l}\text { Popcorn and the } \\
\text { Root Cause }\end{array}$ & $\begin{array}{l}\text { Assume that terrorists are like kernels of popcorn: terrorists are } \\
\text { constantly looking for when the heat is hottest (e.g., when a state's } \\
\text { prestige is on the line during a cease fire); that is when they stage } \\
\text { an event so that they can get as many kernels to pop as possible. } \\
\text { Your task should not be to neutralize the kernels that are going to } \\
\text { pop but rather to turn down the heat so that fewer pop. This } \\
\text { requires determining root causes and demotivating the organization. }\end{array}$ \\
\hline 10 & $\begin{array}{l}\text { The Golden } \\
\text { Message }\end{array}$ & $\begin{array}{l}\text { An important question is whether the effect of a terrorist attack on } \\
\text { recruitment can be mitigated. The most efficient way to reduce the } \\
\text { motivation to join a terrorist organization is by managing the } \\
\text { response. An American response should communicate the golden } \\
\text { message is that America is resilient. }\end{array}$ \\
\hline 11 & Scenario Building & $\begin{array}{l}\text { Scenario building leads to a limitless number of imaginable } \\
\text { scenarios or possibilities. When someone tells a story and provides } \\
\text { a lot of detail, the story becomes entrancing, and that threat or } \\
\text { scenario gets most of the attention and money. }\end{array}$ \\
\hline 12 & $\begin{array}{l}\text { Talk to the } \\
\text { Adversary }\end{array}$ & $\begin{array}{l}\text { We should study the adaptive adversary by looking at and talking to } \\
\text { him. When we start with a logical model, we are really beginning } \\
\text { with a satanic model of the adversary, but this is different from } \\
\text { empirical reality. If we focus on the effect of the adversary's } \\
\text { resentment on his behavior rather than on the disgust, fear, etc., that } \\
\text { his behavior generates, we can better understand the adversary's } \\
\text { thoughts and beliefs and thus are in a better position to counter } \\
\text { them. }\end{array}$ \\
\hline
\end{tabular}




\begin{tabular}{|c|c|c|}
\hline & Title & Description \\
\hline 13 & $\begin{array}{l}\text { Emotionally } \\
\text { Charged } \\
\text { Communications }\end{array}$ & $\begin{array}{l}\text { Much can be learned from the conflicts that terrorist organizations } \\
\text { have with one another. It doesn't matter if the communications are } \\
\text { secret; it just matters if the communications are emotionally } \\
\text { charged. Look at conversation following an event: are the } \\
\text { participants interested in glorifying a cause or in achieving some } \\
\text { other goal? We can learn a lot about an organization by paying } \\
\text { attention to what it is telling its audience; this is called discourse } \\
\text { analysis. It is how we learn about the constituents: the conversation } \\
\text { goes back and forth between "we ought to initiate attacks" and "we } \\
\text { ought to hold back." }\end{array}$ \\
\hline 14 & Lone Wolf & $\begin{array}{l}\text { There are growing numbers of self-motivated and self-educated } \\
\text { homegrown terrorists who simply feel as though they have been } \\
\text { slighted and are waging their own personal jihad. Occurrences of } \\
\text { lone wolf attacks are about } 1 \text { in a million. Logically, then, there are } \\
\text { about } 300 \text { of them in the United States. But without any data, the } \\
\text { lone wolf threat is difficult to assess. Therefore, we ought to look at } \\
\text { the bottleneck: the ability to focus in on those that have both } \\
\text { knowledge and access as well as on those who are beginning to } \\
\text { exhibit telltale signs of radicalization. }\end{array}$ \\
\hline 15 & $\begin{array}{l}\text { Multiple } \\
\text { Objectives and } \\
\text { Multiple Targets }\end{array}$ & $\begin{array}{l}\text { The objective of the foot operative may be different from the } \\
\text { strategic objective of the leadership; the organization is } \\
\text { multilayered and populated by individuals with different, perhaps } \\
\text { competing, objectives. Thus, when evaluating multiple targets, we } \\
\text { need to understand that there may be multiple objectives. Those } \\
\text { potential targets that tend to rise to the top of the pile are those that } \\
\text { achieve several objectives rather than just one. We can learn about } \\
\text { some of these objectives by looking at the documents we capture; } \\
\text { they tell us the types of targets and their values (e.g., The Al Qaeda } \\
\text { Training Manuel, ed. J. Post). }\end{array}$ \\
\hline 16 & $\begin{array}{l}\text { Bureaucratic } \\
\text { Competition }\end{array}$ & $\begin{array}{l}\text { If the United States and the Soviets are competing, there is a game } \\
\text { between the CIA and KGB that is driven by the petty things of } \\
\text { concern to individuals-machismo-rather than the bigger strategy } \\
\text { of national concerns. We might want to think of the competition } \\
\text { between groups as involving more personal issues as well. Perhaps } \\
\text { al-Qaeda operatives are motivated by the desire to show us that } \\
\text { they can do what they do because they've done it before. How } \\
\text { would a model capture that? }\end{array}$ \\
\hline 17 & $\begin{array}{l}\text { Political Violence } \\
\text { as Demand }\end{array}$ & $\begin{array}{l}\text { Political violence may be viewed as a demand issue. When people } \\
\text { become angry, they are more apt to turn to violence. If you can } \\
\text { make them less angry, the demand goes down and the violence } \\
\text { goes down. So it is useful to view it also as a supply issue. Violence } \\
\text { occurs when people can profit by using it. If they want something } \\
\text { from you, you are in a position where you can negotiate; this can } \\
\text { then become a political relationship. }\end{array}$ \\
\hline 18 & $\begin{array}{l}\text { Comfort Level as a } \\
\text { Constraint }\end{array}$ & $\begin{array}{l}\text { Most criminal organizations have a comfort level in terms of what } \\
\text { they are capable of and willing to do. Many don't stray beyond }\end{array}$ \\
\hline
\end{tabular}




\begin{tabular}{|l} 
Title \\
Description \\
their comfort zone. If we harden certain infrastructure, they may \\
continue to target the same areas because they are comfortable with \\
them. What they are not comfortable with may never make it into \\
their playbook.
\end{tabular}

\section{Conclusion}

This paper has summarized the findings from an Adaptive Adversary Workshop, in which we elicited expert opinions on terrorist decision-making and target selections in order to improve our understanding of adversaries (individuals, local/regional groups, transnational groups, states) who may initiate a bioterrorism attack upon U.S. interests. These expert opinions are being used to inform Bayesian Belief Network (BBN) models of terrorist networks, which require substantive information about the intelligent and adaptive adversary who may initiate an attack. To this end, a conceptual framework, informed broadly by the social sciences community, is intended to capture the terrorists' motivations, methods, and decision calculi. 